\title{
Role of Matrix Metalloproteinase-9 in Diagnosis of Dry Eye
}

\author{
AYMAN A. GAAFAR, M.D.; MOHAMED O. YOUSIF, M.D.; BASSEM F. AZIZ, M.D. and \\ NARDEEN ADEL YACOUB, M.Sc.
}

The Department of Ophthalmology, Faculty of Medicine, Ain Shams University

\begin{abstract}
Background: Dry eye is a "multifactorial disease of the tears and ocular surface that results in symptoms of discomfort, visual disturbance, and tear film instability with potential damage to the ocular surface". Symptoms of dry eye, which include visual disturbances and pain/dysesthesias, have been found to negatively impact quality of life.
\end{abstract}

Aim of Study: To assess the presence of ocular surface Matrix Metalloproteinase-9 (MMP-9) in dry eye by InflammaDry® test.

Patients and Methods: A prospective cross-sectional study included a total of 40 eyes with dryness. This study was involved patients visiting outpatient clinic in Qalawoon Hospital from December 2018 till May 2019. The tear film was analyzed for MMP-9 by InflammaDry®test, symptoms and signs of dry eye disease were evaluated using the Ocular Surface Disease Index (OSDI) questionnaire, Tear Breakup Time (TBUT), corneal staining, Schirmer and Meibomian gland examination.

Results: Mean age of the study population was 39.45 years \pm 9.06 SD (range $30-60$ ), sixty five percent of study population were females. Mean of Ocular Surface Disease Index was 23.05 $\pm 5.00 \mathrm{SD}$ (14-33 range), Schirmer test mean was $4.60 \mathrm{~mm} / 5$ minutes $\pm 2.11 \mathrm{SD}(1-8 \mathrm{~mm} / 5 \mathrm{~min}$ range $)$, Tear Breakup Time mean was 5.40 seconds \pm 1.61 SD (3-9 range) and corneal staining mean was $2.45 \pm 0.68 \mathrm{SD}$ (2-4 range). Seventy five percent of the study population had Meibomian glad dysfunction. There was a highly statistically significant correlation between InflammaDry ${ }^{\circledR}$ results and Meibomian glands dysfunction. There were statistically non-significant correlations between Ocular surface disease index, Schirmer test results, tear breakup time, corneal staining and positive results of InflammaDry®test.

Conclusion: There is direct correlation between inflammation and dry eye disease. Also, Matrix metalloproteinase testing in dry eye disease is a valuable new diagnostic tool to identify the presence of ocular surface inflammation.

Key Words: Matrix Metalloproteinase-9-Dry eye.

Correspondence to: Dr. Nardeen Adel Yacoub, E-Mail: Nardeen adel304@yahoo.com

\section{Introduction}

DRY eye is a "multifactorial disease of the tears and ocular surface that results in symptoms of discomfort, visual disturbance, and tear film instability with potential damage to the ocular surface" [1].

Symptoms of dry eye, which include visual disturbances and pain, have been found to negatively impact quality of life [2].

Due to the multifactorial etiology of dry eye and its varied pathophysiologic mechanisms, it has been difficult to identify specific biomarkers that can aid in the diagnosis of dry eye. Inflammation is known to play an important role in the initiation and propagation of dry eye [3]

Matrix Metalloproteinase-9 (MMP-9) is a 23 zinc and calcium ion-dependent enzyme important for tissue remodeling in normal physiological processes like wound healing and bone development. It plays a pathogenic role in inflammatory diseases, arthritis, cardiovascular diseases, pulmonary diseases, and cancer [4].

MMP-9 activity is regulated by epigenetic processes, cell-cell interactions, and cytokinemediated pathways. On the corneal surface, the hyperosmolarity of the tear fluid seen in dry eye has been shown to trigger the Stress-Activated Protein Kinase (SAPK) signaling cascade. SAPK signaling leads to the release of MMP-9 from corneal epithelial cells themselves, thus initiating a cycle of progressive inflammation. Tight junction proteins; occludin and Zonula Occludens-1 (ZO1) are cleaved by MMP-9, thereby disrupting epithelial layers [5].

T-cell recruitment, the proteolytic activity of the MMP-9 molecule itself, and activation of se- 
cretion of additional cytokines initiate a selfperpetuating cycle of inflammation, secretory dysfunction, and worsening eye dryness [6].

In this study, we will use InflammaDry (RPS, Sarasota, FL), a novel test to measure level of MMP-9. It measures the presence of MMP-9. The test provides a qualitative (yes/no) response. The lower detection limit of the test is $40 \mathrm{ng} / \mathrm{ml}$. If the collected sample is less than 5 L, thest may falsely give a negative result [7] .

\section{Aim of the work:}

To assess the presence of ocular surface Matrix Metalloproteinase-9 (MMP-9) in dry eye by InflammaDry® test.

\section{Patients and Methods}

A prospective cross-sectional study conducted on 40 eyes of forty patients attending outpatient clinic in Qalawoon Hospital from December 2018 till May 2019. The study was conducted on patients with dry eye. Exclusion criteria included; contact lens wearer, previous refractive, cataract, glaucoma and retinal surgery within last six months, collagen vascular disease, HIV, sarcoidosis, pulmonary and cardiac diseases, graft-versus host disease, history of cancer therapy either chemotherapy or radiotherapy and history of using ocular medications as steroids \& anti-glaucoma medications. The tear film was analyzed for MMP-9 by InflammaDry® test. Symptoms and signs of dry eye disease were evaluated using the OSDI questionnaire, TBUT, corneal staining, Schirmer and Meibomian gland examination.

\section{Statistical analysis:}

Data were collected, revised, coded and entered to the Statistical Package for Social Science (IBM SPSS) version 23 . The quantitative data were presented as mean, standard deviations and ranges when their distribution was found parametric. Also, qualitative variables were presented as number and percentages. The confidence interval was set to $95 \%$ and the margin of error accepted was set to $5 \%$. So, the $p$-value $<0.05$ was considered significant.

\section{Results}

This study was conducted on 40 eyes of 40 patients with dry eye disease, $65 \%$ of the study populations were females and $35 \%$ were males. The mean age was 39.45 years \pm 9.06 SD (30-60 years range) as shown in (Table 1).
Table (1): Demographic data of the study group.

\begin{tabular}{cl}
\hline & No. $=40$ \\
\hline Age (years): & \\
Mean \pm SD & $39.45 \pm 9.06$ \\
Range & $30-60$ \\
Sex: & \\
Female & $26(65.0 \%)$ \\
Male & $14(35.0 \%)$ \\
\hline
\end{tabular}

No: Number.

SD: Standard Deviation.

In this study we found non-significant correlation between the age and sex of study group and inflammaDry® test results whether the results were negative or positive as shown in (Table 2).

Table (2): Correlation between inflammaDry® test results and demographic distribution of study population.

\begin{tabular}{|c|c|c|c|c|c|}
\hline & \multicolumn{2}{|c|}{$\begin{array}{l}\text { InflammaDry® test for } \\
\text { matrix metalloproteinase-9 }\end{array}$} & \multirow{2}{*}{$\begin{array}{c}\text { Test } \\
\text { value }\end{array}$} & \multirow{2}{*}{$\begin{array}{c}p- \\
\text { value }\end{array}$} & \multirow{2}{*}{ Sig. } \\
\hline & $\begin{array}{l}\text { Negative } \\
\text { No. }=4\end{array}$ & $\begin{array}{l}\text { Positive } \\
\text { No. }=36\end{array}$ & & & \\
\hline $\begin{array}{l}\text { Age (years): } \\
\text { Mean } \pm \mathrm{SD} \\
\text { Range }\end{array}$ & $\begin{array}{l}39.50 \pm 2.89 \\
37-42\end{array}$ & $\begin{array}{l}39.44 \pm 9.52 \\
30-60\end{array}$ & $0.011^{\bullet}$ & 0.991 & NS \\
\hline $\begin{array}{l}\text { Sex: } \\
\text { Female } \\
\text { Male }\end{array}$ & $\begin{array}{l}4(100.0 \%) \\
0(0.0 \%)\end{array}$ & $\begin{array}{l}22(61.1 \%) \\
14(38.9 \%)\end{array}$ & $2.393 *$ & 0.122 & NS \\
\hline $\begin{array}{l}\text { No: Number. } \\
\text { SD: Standard D } \\
p \text {-value }>0.05 \text { : }\end{array}$ & on-Significa & (S) & $\begin{array}{l}\text { Chi-squa } \\
\text { adepend }\end{array}$ & $\begin{array}{l}\text { e test. } \\
\text { nt } t \text {-test. }\end{array}$ & \\
\hline
\end{tabular}

Table (3): Relations between results of inflammaDry ${ }^{\circledR}$ and other diagnostic tests for dry eye disease.

\begin{tabular}{|c|c|c|c|c|c|}
\hline & \multicolumn{2}{|c|}{$\begin{array}{l}\text { InflammaDry® test for } \\
\text { matrix metalloproteinase-9 }\end{array}$} & \multirow{2}{*}{$\begin{array}{c}\text { Test } \\
\text { value• }\end{array}$} & \multirow{2}{*}{$\begin{array}{c}p- \\
\text { value }\end{array}$} & \multirow{2}{*}{ Sig. } \\
\hline & $\begin{array}{l}\text { Negative } \\
\text { No. }=4\end{array}$ & $\begin{array}{l}\text { Positive } \\
\text { No. }=36\end{array}$ & & & \\
\hline $\begin{array}{l}\text { Ocular surface } \\
\text { disease index: } \\
\text { Mean } \pm \mathrm{SD} \\
\text { Range }\end{array}$ & $\begin{array}{l}25.50 \pm 0.58 \\
25-26\end{array}$ & $\begin{array}{l}22.78 \pm 5.20 \\
14-33\end{array}$ & 1.035 & 0.307 & NS \\
\hline $\begin{array}{l}\text { Schirmer test } \\
(\mathrm{mm} / 5 \mathrm{~min}): \\
\text { Mean } \pm \mathrm{SD} \\
\text { Range }\end{array}$ & $\begin{array}{l}4.00 \pm 1.15 \\
3-5\end{array}$ & $\begin{array}{l}4.67 \pm 2.19 \\
1-8\end{array}$ & -0.595 & 0.556 & NS \\
\hline $\begin{array}{l}\text { Tear breakup ti } \\
\text { test }(\text { sec }): \\
\text { Mean } \pm \text { SD } \\
\text { Range }\end{array}$ & $\begin{array}{l}4.00 \pm 0.00 \\
4-4\end{array}$ & $\begin{array}{l}5.56 \pm 1.63 \\
3-9\end{array}$ & -1.888 & 0.067 & NS \\
\hline $\begin{array}{l}\text { Corneal stainin } \\
\text { Mean } \pm \text { SD } \\
\text { Range }\end{array}$ & $\begin{array}{l}2.50 \pm 0.58 \\
2-3\end{array}$ & $\begin{array}{l}2.44 \pm 0.69 \\
2-4\end{array}$ & 0.154 & 0.879 & NS \\
\hline $\begin{array}{l}\text { No : Number. } \\
\text { SD : Standard } \\
\text { mm : Millimete } \\
\text { min : Minutes. } \\
\text { sec : Seconds. } \\
p \text {-value >0.05: } \\
-: \text { Independent }\end{array}$ & $\begin{array}{l}\text { iation. } \\
\text {-Significant } \\
\text { t. }\end{array}$ & & & & \\
\hline
\end{tabular}


There were statistically non-significant correlations between ocular surface disease index and inflammaDry ${ }^{\circledR}$ test results. As well as there were statistically non-significant correlations between Schirmer test and results of inflammaDry ${ }^{\circledR}$ test. We found also that there were statistically nonsignificant correlations between tear breakup time and results of inflammaDry ${ }^{\circledR}$ test. Also, the correlations between corneal staining and results of inflammaDry ${ }^{\circledR}$ test are statistically non-significant as shown in (Table 3).

Among the study group there were thirty eyes have Meibomian gland dysfunction and positive results of inflammaDry ${ }^{\circledR}$ test. Also, we found six eyes have normal Meibomian glands and positive results. The relation between Meibomian glands dysfunction and results of inflammaDry ${ }^{\circledR}$ test is highly significant with $p$-value $<0.01$ as shown in (Table 4).

Table (4): Relation between Meibomian gland assessment and results of inflammaDry ${ }^{\circledR}$ test.

\begin{tabular}{|c|c|c|c|c|c|c|c|}
\hline \multirow{3}{*}{$\begin{array}{l}\text { Meibomian gland } \\
\text { assessment }\end{array}$} & \multicolumn{4}{|c|}{$\begin{array}{c}\text { InflammaDry® } \\
\text { test for matrix } \\
\text { metalloproteinase-9 }\end{array}$} & \multirow{3}{*}{$\begin{array}{c}\text { Test } \\
\text { value* }\end{array}$} & \multirow{3}{*}{$\begin{array}{c}p- \\
\text { value }\end{array}$} & \multirow{3}{*}{ Sig. } \\
\hline & \multicolumn{2}{|c|}{ Negative } & \multicolumn{2}{|c|}{ Positive } & & & \\
\hline & No. & $\%$ & No. & $\%$ & & & \\
\hline $\begin{array}{l}\text { - Normal } \\
\text { - Meibomian gland } \\
\text { dysfunction }\end{array}$ & $\begin{array}{l}4 \\
0\end{array}$ & $\begin{array}{l}100.0 \\
0.0\end{array}$ & $\begin{array}{l}6 \\
30\end{array}$ & $\begin{array}{l}16.7 \\
83.3\end{array}$ & 13.333 & 0.000 & HS \\
\hline
\end{tabular}

\section{Discussion}

Dry eye is often underdiagnosed because of the poor correlation between commonly used objective signs and symptoms and the variability of signs over time [8].

Matrix metalloproteinase 9 is an inflammatory biomarker that has been shown to be elevated in the tears of dry eye patients. The possibility to detect elevated MMP-9 levels accurately in the tear film may lead to earlier diagnosis and improved treatment of ocular surface disease [9].

This study included 40 eyes visiting the outpatients clinic of Qalawoon Eye Hospital, Cairo, who satisfied the inclusion and exclusion criteria between December 2018 and May 2019 aiming to determine MMP-9 in dry eye disease.

This study showed that $90 \%$ of patients with dry eye disease had InflammaDry positive results which detect presence of MMP-9. This high per- centage results can be explained by various factors like effect of environment, humidity and stress which can increase level of MMP-9 in tear film as reported by Teson et al., [10] .

Sambursky et al., [7] published the sensitivity and specificity of a point-of-care MMP-9 immunoassay (InflammaDry), in their prospective study incorporating 143 patients with dry eye and 63 controls, $85 \%$ of patients with dry eye had positive InflammaDry results and elevated MMP-9, and $6 \%$ of the control group had positive results.

Sambursky et al., [3] in another prospective study reported that $81 \%$ of patients with dry eye had InflammaDry positive results. Also, Sambursky [11] in a retrospective study on 100 patients reported that $60 \%$ of the patients with dry eye symptoms tested positive for elevated MMP-9.

However, Lanza et al., [4] reported that 39\% of participants with dry eye symptoms showed positive results for MMP-9 using the InflammaDry. Because the InflammaDry shows positive results only when the MMP-9 level in the tears is more than $40 \mathrm{ng} / \mathrm{ml}$, most of the study patients would have shown negative results. Lanza assumed that dry eye patients tested in recent studies belong in this gray zone.

Messmer et al., [12] who conducted a study on 47 patients with dry eye and 54 controls, found that 19 of 47 patients confirmed with dry eye $(40.4 \%)$ and in 3 of 54 controls (5.6\%), the MMP9 results were positive. This difference was statistically significant $(p<0.001)$. Thus, the MMP-9 results indicated a clinically significant inflammation in $40 \%$ of dry eye patients.

This study showed a female predominance (65.0\%), it correlates with other studies as Messmer et al., [12] who found a female predominance $66.0 \%$ and Sambursky [11] who found that female patients represented $72 \%$ of the study population.

On the other hand, Lanza et al., [4] reported that male patients represented $90 \%$ of the study population.

This difference in female/male ratio can be explained in part by their greater percentage in the population.

This study showed that there is a highly significant correlation between MMP-9 and Meibomian gland dysfunction. This coincides with other studies as Aragona et al., [5] and Messmer et al., [12] who showed that MMP-9 positive results correlated 
with the number of obstructed Meibomian ducts and a pathologic Meibomian gland secretion.

While, Lanza et al., [4] found that there was a statistically non-significant correlation between MMP-9 on the ocular surface and MGD whether patients were positive or negative.

In this study a statistically non-significant correlation was found between MMP-9 and subjective symptoms evaluated by OSDI. This result coincides with that found in other studies as Schargus et al., [13], Aragona et al., [5] and Lanza et al., [4].

While Messmer et al., [12] showed that positive results of InflammaDry test correlated well with subjective symptoms of dry eye disease evaluated by OSDI. Possible explanation for the discordance between dry eye symptoms and elevated MMP-9 may be the intermittent nature of mild dry eye disease, which leads to symptoms only at the time of an environmental stress. Also, OSDI is a subjective method to evaluate symptoms of dry eye.

In this study also, we found a statistically nonsignificant correlation between MMP-9 positive results and Schirmer test results. This result coincides with that found in other studies as Schargus et al., [13], Aragona et al., [5] and Lanza et al., [4]

However, Messmer et al., [12] showed that there was a statistically significant correlation between positive results of InflammaDry test and Schirmer test results.

In this study also, a statistically non-significant correlation was found between MMP-9 positive results and TBUT. This correlates with that reported by Schargus et al., [13] and Lanza et al., [4] .

While, Messmer et al., [12] showed that positive results of InflammaDry test correlated well with TBUT.

In this study also, there were a statistically nonsignificant correlation between MMP-9 positive results and corneal staining. This result coincides with that reported by Lanza et al., [4] .

However, Schargus et al., [13] and Messmer et al., [12] showed significant correlation between results of MMP-9 and corneal staining. This variation may have occurred because of the disadvantage of staining, as dry eye cannot be clinically differentiated from other conditions that lead to ocular surface staining such as poor lid apposition and medication toxicity.

\section{Conclusion:}

There is direct correlation between inflammation and dry eye disease. Also, Matrix metalloproteinase testing in dry eye disease is a valuable new diagnostic tool to identify the presence of ocular surface inflammation.

\section{References}

1- FOULKS G.N., JESTER J., SUTPHIN J., MURUBE J., LEMP M.A., BAUDOUIN C., BAUM J., DOGRU M. and KINOSHITA S.: The definition and classification of dry eye disease: Report of the Definition and Classification Subcommittee of the International Dry Eye Work Shop. Ocul. Surf., 5: 75-92, 2007.

2- POUYEH B., VITERI E., FEUER D.J. LEE and H. FLOREZ: Impact of ocular surface symptoms on quality of life in a United States veterans affairs population. Am. J. Ophthalmol., 153: 1061-6, 2012.

3- SAMBURSKY R., DAVITT W.F., FRIEDBERG M. and TAUBER S.: Prospective, multicenter, clinical evaluation of point-of-care matrix metalloproteinase-9 test for confirming dry eye disease. Cornea, 33: 812-8, 2014.

4- LANZA N.L., VALENZUELA F., PEREZ V.L. and GALOR A.: The matrix metalloproteinase 9 point-of-care test in dry eye. Ocul. Surf., 14: 189-95, 2016.

5- ARAGONA P., AGUENNOUZ M., RANIA L., POSTORINO E., PISANI A., PUZZOLO D., SOMMARIO M.S. and ROSZKOWSK A.M.: Matrix metalloproteinase 9 and transglutaminase 2 expression at the ocular surface in patients with different forms of dry eye disease. Ophthalmology, 122: 62-71, 2015.

6- HESSEN M. and AKPEK E.K.: Dry eye: An inflammatory ocular disease. J. Ophthalmic. Vis. Res., 9: 240-50, 2014.

7- SAMBURSKY R., DAVITT W.F. and LATKANY R.: Sensitivity and specificity of a point-of-care matrix metalloproteinase-9 immunoassay for diagnosing inflammation related to dry eye. JAMA Ophthalmol., 131: 24-8, 2013.

8- SOLOMON A., DURSUN D., LIU Z., XIE Y., MACRI A. and PFLUGFELDER S.C.: Pro-and anti-inflammatory forms of interleukin- 1 in the tear fluid and conjunctiva of patients with dry eye disease. Invest. Ophthalmol. Vis. Sci., 42: 2283-92, 2001.

9- SULLIVAN B.D., CREWS L.A., MESSMER E.M., FOULKS G.N., NICHOLS K.K., BAENNINGER P. and LEMP M.A.: Correlations between commonly used objective signs and symptoms for the diagnosis of dry eye disease: Clinical implications. Acta Ophthalmol., 92: 1616, 2014.

10- TESON M., GONZALEZ-GARCIA M.J., LOPEZ-MIGUEL A., ENRÍQUEZ-De-SALAMANCA A., MARTÍNMONTAÑEZ V., BENITO M.J. and CALONGE M. Influence of a controlled environment simulating an inflight airplane cabin on dry eye disease. Invest. Ophthalmol. Vis. Sci., 54: 2093-9, 2013.

11- SAMBURSKY R.: Presence or absence of ocular surface inflammation directs clinical and therapeutic management of dry eye. Clinl. Ophthalmol., 10: 23-37, 2016. 
12- MESSMER E.M., VON LINDENFELS V., GARBE A and KAMPIK A.: Matrix metalloproteinase 9 testing in dry eye disease using a commercially available point-of-care immunoassay. Ophthalmology, 123: 2300-8, 2016.
13- SCHARGUS M., IVANOVA S., KAKKASSERY V., DICK H.B. and JOACHIM S.: Correlation of tear film osmolarity and 2 different MMP-9 tests with common dry eye tests in a cohort of non-dry eye patients. Cornea, 34: 739-44, 2015.

\section{دور الماتريكس ميتالوبروتينيز-9 فى تشخيص مرض جفاف العين}

جفاف العين هو مرض متعدد العوامل يؤثر على الدموع وسطح العين ويؤدى إلى آعراض عدم الراحة، وإضطراب البصرية، وعدم إستقرار الدموع على سطح العين.

في هذه الدراسة المستعرضة، سوف نتناول مفتاح اللسئال المهم: هل يلعب الإلتهاب آى دود في الآلية الفيسيولوجيا والمرضية المئية المسيبة لجفاف العين؟ لذلك، قمنا بتقييم وجود إنزيم "الماتريكس ميتالوبروتينيز-9"، وهو الإنزيم الذى يلعب دوراً آساسياً في الإلتهاب.

خضع جميع المشاركين التقييم مؤشر الآمراض السطحية للعين، وإختبار شيرمر، وإختبار وقت تكسير للدموع، وصبغة القرنية وإختبار "الإنفلاما دراى" الذى يكشف عن وجود إنزيم "الماتريكس ميتالوبروتينيز" فى الدموع.

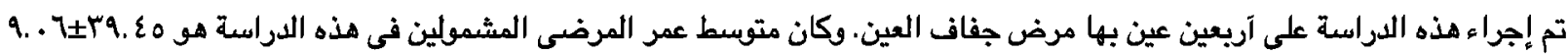

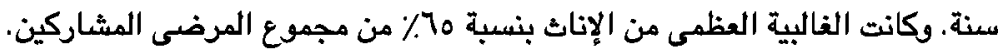

فى هذه الدراسة وجدنا آن هناك علاقة ذات دلالة إحصائية هامة بين خلل غدد "مييومين" والنتائج الإيجابية لإختبار "الإنفلاما دراي". وقد وجدنا آيضاً علاقة ليست ذات دلالة إحصائية هامة بين النتائج الإيجابية لإختبار "الإنفلاما دراى" وكل من مؤشر الآمراض السطحية

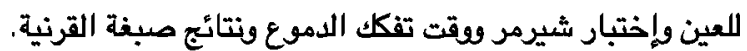

ذيى هذه الدراسة وجدنا علاقة ليست ذات مغزى إحصانى هام بين عمر وجنس مجموعة الدراسة ونتائج إختبار "الإنفلاما دراي" سواء ما إذا كانت النتائج سلبية آو إيجابية. 